\title{
Ativos territoriais, estratégias de desenvolvimento e governança territorial: uma análise comparada de experiências brasileiras e portuguesas ${ }^{1}$
}

Valdir Roque Dallabrida. Universidade do Contestado, Canoinhas, Santa Catarina, Brasil.

RESUmo | Possuir ativos com algum grau de especificidade, em geral, é considerado uma vantagem diferenciadora para determinados territórios. Exemplificando, experiências de Indicação Geográfica no Brasil e de Denominaçóes de Origem Controlada ou Protegida em Portugal estão entre as principais estratégias de especificação de ativos territoriais. São quase inexistentes estudos sistemáticos e comparados sobre a eficácia dos sistemas de governança territorial utilizados em tais experiências. Através do recurso a estudos documentais e bibliográficos, visitações, entrevistas e aplicação de um inquérito por questionário se analisa criticamente a relação entre ativos territoriais, estratégias de desenvolvimento e governança territorial. Os resultados da análise permitem afirmar que: tais formas de especificação são uma opção, não necessariamente a única e, em alguns casos, nem a mais significativa; há desafios não superados em relação aos sistemas de governança territorial; o recurso ao associativismo e à diferenciação, em geral, não passa de uma estratégia que viabiliza negócios lucrativos privados.

PALAVRAS-CHAVE | economia regional, gestão territorial, desenvolvimento territorial.

ABstract | Possessing assets with some level of specificity, in general, is considered a comparative advantage for certain territories. For example, experiences in the Brazil Geographical Indication and Controlled or Protected Denominations of Origin in Portugal are among the main strategies of specification territorial assets. Systematic and compared studies on the effectiveness of territorial governance systems used in such experiences are almost nonexistent. The relationship of territorial assets, development strategies and territorial governance is critically analyzed through documentary and bibliographical studies, visitations, interviews and a questionnaire survey. The results of the analysis allow us to state that: such forms of specification are an option, not necessarily the only one, and in some cases, not the most significant one, there are unresolved challenges related to territorial governance systems, recourse to associativism and the differentiation, in general, no more than a strategy which makes possible private-profit business.

KEY WORDS | regional economy, territorial management, territorial development.

Recibido el 11 de marzo de 2014, aprobado el 26 de noviembre de 2015

E-mail: valdirdallabrida@gmail.com

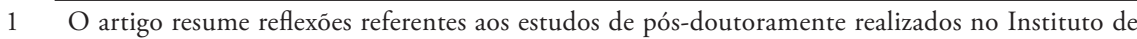
Ciências Sociais da Universidade de Lisboa, sob a orientação do Prof. Dr. João Ferrão. Além disso, integra-se em dois Projetos de Pesquisa: Signos Distintivos Territoriais e Indicação Geográfica: um estudo sobre os desafios e perspectivas como alternativa de Desenvolvimento Territorial, juntamente com colegas do Grupo de Estudos sobre Desenvolvimento Regional (GEDER), com financiamento do CNPq; Estratégias de especificação de Ativos Territoriais como alternativa de Desenvolvimento, referente à Bolsa Produtividade em Pesquisa do CNPq/2013-2016. 


\section{Introduçáo}

Ativos territoriais são fatores em uso, utilizados na produção de mercadorias ou serviços num determinado território. Já os recursos são fatores a revelar, a desenvolver ou a organizar como potenciais reais. As estratégias de especificação de ativos territoriais podem ser consideradas formas de valorização das vantagens sustentáveis dos territórios, na perspectiva de contribuir para a qualificação de seu processo de desenvolvimento. As experiências de Indicação Geográfica (IGs) no Brasil e de Denominação de Origem Controlada ou Protegida (Doc/Dop) em Portugal, ou outras formas organizacionais correlatas, são exemplos dessas estratégias de especificação.

A questão da especificação de ativos territoriais e da sua relação com os processos de desenvolvimento está sustentada em abordagens teóricas que reafirmam a importância da instância territorial. Esta postura teórica náo significa adotar um enfoque estritamente localista. Trata-se, sim, de recuperar contemporaneamente o território como construção social. Ou seja, ao invés do fim da geografia e dos territórios, argumento que chegou a ser defendido no final do Século xx (Friedman, 2005; O’Brien, 1992), assistimos a um processo de desterritorializaçáo, ou seja, de precarização socioespacial promovido por um sistema econômico altamente concentrador (Haesbaert, 2006), que estimula e pressupóe formas de integração global fortemente assimétricas.

Sobre o tema em referência, Santos (2005) considera que, cada vez mais, os territórios são formados de lugares contíguos (que ele chama de espaço banal, o espaço de todos) e de lugares em rede. O autor salienta, no entanto, que os mesmos lugares que formam redes formam também o espaço banal, contendo, simultaneamente, funcionalidades diferenciadas. Sustenta sua afirmaçáo relembrando que além das redes e com as redes existe o espaço banal, o espaço de todos, todo o espaço, porque as redes constituem apenas uma parte do espaço e o espaço de alguns.

Na obra referida, Santos (2005) profere uma célebre frase, que pode dialogar com o tema que aqui está sendo tratado, ao fazer referência à maneira como alguns produtores rurais brasileiros, na década de 1990, defendiam seus interesses, por exemplo, ofertando no mercado produtos cultivados agroecologicamente, o que permitia passar de um consumo puramente econômico para um consumo político. Considerando aquele contexto, defendia, então, a construção de novas horizontalidades, que permitissem “(...) a partir da base da sociedade territorial, encontrar um caminho que nos liberte da maldição da globalização perversa que estamos vivendo e nos aproxime da possibilidade de construir uma outra globalização, capaz de restaurar o homem na sua dignidade" (p. 260).

Na mesma linha de argumentação, Pecqueur (2009), fazendo menção à possibilidade de avançar da vantagem comparativa à vantagem diferenciadora, critica o modelo ricardiano de troca internacional baseado nas vantagens comparativas, abordagem que pressupóe a ideia de comparabilidade e, portanto, de equivalência geral das ofertas em um mercado essencialmente competitivo. $\mathrm{O}$ autor afirma que essa náo é a realidade que se constata no mundo contemporâneo, sendo mais 
comum a situação em que se instala um modelo de concorrência no qual somente as economias com baixo custo de produção podem triunfar. Assim, segundo o autor, uma saída para o problema consistiria na diferenciação dos produtos dos territórios. Os sinais distintivos de um território, sua especificidade, seriam entendidos, então, como uma vantagem diferenciadora.

Muito foi escrito já sobre o tema em questão. No entanto, entende-se ser necessário aprofundar a dimensão relacionada às diferentes estratégias de especificação de ativos territoriais com o foco em uma questão central: qual a contribuição efetiva dos sistemas de governança territorial de estratégias baseadas na especificação de ativos territoriais para a sustentabilidade social, econômica e ambiental dos territórios envolvidos?

Esta questão de investigação parte da seguinte hipótese: a legislação brasileira e internacional considera os sinais distintivos de um território como marcas e atributos da coletividade territorial, o que gera a expectativa de apropriaçáo coletiva dos seus resultados nas experiências de especificação de ativos territoriais, mas este resultado não tem sido alcançado, em parte pela inexistência de sistemas adequados de governança territorial.

Para validar esta hipótese foram realizados estudos sobre a eficácia dos sistemas de governança territorial de dez experiências de especificação de ativos territoriais do Brasil e de Portugal. Por eficácia dos sistemas de governança territorial entendemos, neste caso, a capacidade efetiva destes contribuírem para a sustentabilidade social, econômica e ambiental dos territórios em causa. Essa capacidade depende, em grande medida, da qualidade das práticas de governança territorial.

Além desta introdução, o texto está estruturado em mais quatro partes: (a) o aprofundamento teórico sobre temas como território, identidade territorial, desenvolvimento e governança territorial, ativos e recursos territoriais; (b) a explicitação dos procedimentos metodológicos e da amostra investigada; (c) a análise dos resultados e (d) as consideraçóes finais.

\section{Referencial teórico}

O debate contemporâneo sobre desenvolvimento contempla diferentes subtemas, dependendo da área do conhecimento. Na Geografia, um subtema recorrente é o debate sobre território, territorialidade e identidade territorial e sua relação com o desenvolvimento. São referenciais que dialogar com o tema aqui abordado: ativos territoriais, estratégias de desenvolvimento e governança territorial.

\section{Território e territorialidade}

Há concordância por parte de autores da Geografia de que território é uma construção social resultante de relaçóes de poder. No território expressam-se, simultaneamente, dimensôes de unidade e de conflitualidade. São relaçóes de caráter social, político, econômico e cultural, por vezes até religioso, inseridas na história de uma sociedade situada territorialmente. Portanto, o território precisa ser compreendido numa perspectiva integradora, ou seja, como um domínio politicamente estruturado e também como apropriação simbólica, identitária, inerente a certa classe social e 
ao produto gerado por ela (Haesbaert, 2006). Além disso, é necessário considerar a perspectiva relacional para o território, enfatizando a multidimensionalidade de poderes que sobre ele se fazem sentir (Raffestin, 1993).

Neste texto, assume-se a definiçáo proposta por Dallabrida (2006, p. 161), que integra as preocupaçóes dos autores citados: "O conceito de território refere-se a uma fração do espaço historicamente construída através das interelaçôes dos atores sociais, econômicos e institucionais que atuam nesse âmbito espacial, apropriada a partir de relaçóes de poder sustentadas em motivaçóes políticas, sociais, econômicas, culturais ou religiosas, oriundas do Estado, de grupos sociais ou corporativos, instituiçóes ou indivíduos". Os territórios são produzidos espaço-temporalmente pelo exercício de poder de um determinado grupo social, para o atendimento das suas territorialidades cotidianas (Saquet, 2015).

Sobre territorialidade, esta corresponde às relaçôes sociais e às atividades diárias que os homens têm com seu entorno, sendo resultado do processo de produção de cada território, assumindo um papel fundamental para a construção da identidade e para a reorganização da vida quotidiana (Saquet, 2003). Raffestin (2015), referindose aos principais autores referenciais, afirma haver convergência em relação a duas questóes: o conceito de território enquanto resultado de um processo de produçáo e o de territorialidade enquanto sistema de relaçóes.

A territorialidade pode ser edificada através do estímulo aos laços identitários e ao fortalecimento do capital social e cultural, promovendo a valorização, proteção e capitalização das especificidades culturais, das tipicidades, do patrimônio ambiental, das práticas produtivas e das potencialidades econômicas (Albagli, 2004).

Considerar a condição multidimensional do território implica admitir que sua concepção não fizesse referência apenas às relaçóes de posse nem de poder, envolvendo, também, as relaçôes e os processos socioeconômicos e ambientais. Assume-se aqui uma concepção multidimensional de território e de territorialidade. Trata-se de uma concepção que poderá orientar o redimensionamento das relaçóes de poder e a proposição de alternativas de desenvolvimento que valorizem a(s) identidade(s) territorial(is), o que estabelece profundas relaçóes com a questão dos ativos territoriais e seus impactos no desenvolvimento dos territórios.

\section{Território e identidade territorial}

$\mathrm{O}$ fato dos autores anteriormente referenciados afirmarem que a territorialidade deve estar edificada sobre laços identitários sublinha a importância da identidade territorial. Sobre a relação entre território e identidade, há uma relação cumulativa entre ambos. "Enquanto se, por um lado, a identidade territorial gera e orienta os processos de territorialização, por outro lado estão as mesmas açôes de territorialização a reforçar o processo de identificação entre a comunidade e o seu espaço vivido" (Pollice, 2010, p. 9). Na mesma linha de argumentação, Caldo (1996, p. 285) descreve a identidade geográfica como uma “(...) relação identitária que liga uma determinada comunidade ao seu espaço vivido”. Ao fazer referência ao espaço vivido, o autor quer reforçar que não está a se referir apenas à dimensão espacial do fenômeno identitário, mas também àquelas ligaçôes de pertença que constituem o território em si. 
É importante ressaltar que a identidade territorial é dinâmica, mudando no tempo à semelhança de todos os outros componentes territoriais. Esta constatação nos ajuda a estabelecer uma relação entre identidade e inovação territorial, apesar de ela ser aparentemente contraditória. "A identidade territorial, onde oportunamente valorizada, pode contribuir ao desenvolvimento e à implementação dos processos inovadores em escala local" (Pollice, 2010, p. 11).

Mas o dinamismo da identidade territorial não é uma questão dada, pois ao mudar a identidade territorial mudam também os símbolos dessa identidade. Às vezes esta mudança é estimulada pela própria representação que os atores externos fazem do território e da sua especificidade (Pollice, 2010). É importante lembrar que esta pressão no sentido de interferir na mudança de percepção da identidade territorial pode também ser arquitetada pela elite local, com o propósito de levar ao esquecimento traços identitários do território que revelem situaçôes socioeconômico-culturais que venham a condenar açóes do passado, contrariando os interesses de tais atores hegemônicos. Nestes casos, o lugar se adapta à imagem atribuída desde fora do território, contribuindo para a perda da identidade local. Assim, tais pressôes externas podem ser entendidas como formas de manipulação das identidades territoriais, como estratégia de controle do território (Pollice, 2010).

Uma crítica sobre os debates em relação à identidade territorial é a que considera que a mistificação dos valores identitários territoriais revela formas fechadas de identidade, fundadas sobre identidades historicamente sucessivas ou sobre a revitalização artificial de tradiçóes já perdidas (Pollice, 2010). Entende-se, no entanto, que os limites entre a defesa da preservação da identidade territorial e a necessidade de inovação não são necessariamente evidentes, exigindo, portanto, uma avaliação caso a caso.

\section{Identidade territorial e desenvolvimento}

Partindo do argumento de que é em torno da própria matriz identitária que o lugar se estrutura e se diferencia do entorno geográfico, é possível estabelecer uma relação próxima entre identidade e desenvolvimento territorial. Neste sentido, toda a estratégia de desenvolvimento precisa se sustentar em uma base conceitual ampla, que contemple os aspectos relativos à identidade cultural dos territórios e não somente focada nas externalidades de um determinado produto, processo ou serviço (Sacco dos Anjos \& Caldas, 2010).

Referindo-se aos possíveis impactos da identidade territorial no processo de desenvolvimento, Pollice (2010, p. 18-20) destaca sete aspectos: (1) a identidade territorial tende a reforçar o poder normativo dos valores éticos e comportamentais localmente compartilhados; (2) a identidade territorial contribui para melhorar a transferência intrageracional e intergeracional do saber; (3) o sentido de pertença constitui o cimento do sistema econômico territorial; (4) é necessário que o conjunto de empresas locais se fundamente numa reinterpretação crítica e inovadora, pois a capacidade de auto-organização dos sistemas territoriais está profundamente ligada à possibilidade de criar alguns mecanismos de introjeção da mudança; (5) o desenvolvimento endógeno se substancia na capacidade da comunidade local de valorização do território, em particular, àqueles recursos não localizáveis que constituem 
elemento de diferenciação; (6) a expressão mais significativa desta relação identitária entre a estratégia de desenvolvimento e a cultura do território é dada por mecanismos de convergência política e de compartilhamento projetual, reduzindo os comportamentos oportunistas ou ideológicos das forças que ali se confrontam; (7) os sentimentos identitários determinam, no nível local, um apego afetivo aos valores paisagísticos e culturais do território.

Consideram-se como fundamentais os aspectos ressaltados pelo autor, tendo em vista o tema do presente artigo. Para reafirmar a relação entre ativos com especificidade territorial, identidade e desenvolvimento territorial, assume-se a perspectiva teórica expressa em Dallabrida (2015, p. 325).

O desenvolvimento territorial é entendido como um processo de mudança continuada, situado histórica e territorialmente, mas integrado em dinâmicas intraterritoriais, supraterritoriais e globais, sustentado na potenciação dos recursos e ativos (materiais e imateriais, genéricos e específicos) existentes no local, com vistas à dinamização socioeconômica e à melhoria da qualidade de vida da sua população.

Um dos elementos teóricos presentes na concepção aqui assumida é o fato de que contam não somente os recursos e ativos materiais, mas também os imateriais ou intangíveis, bem como a distinção entre genéricos e específicos. Os fatores intangíveis manifestam-se territorialmente em situaçôes ou comportamentos perceptíveis, tais como a propensão empreendedora, o nível cultural, o espírito colaborativo, a ética comportamental, a sensibilidade estética, dentre outros.

Por fim, é fundamental registrar que, ao abordar a relação entre território e desenvolvimento, não se deve desconsiderar o fato de que, apesar do poder de autonomia atribuído à escala territorial, os territórios estão inseridos num mundo globalizado, em que a multiescalaridade dos processos está presente (Brandão, 2007; Fernández \& Dallabrida, 2008; Swyngedouw, 2010). Essa constatação não relativiza a argumentação teórica aqui referida, mas revela a complexidade em que o tema se situa, tanto teoricamente quanto no contexto da realidade socioeconômica e cultural.

\section{Desenvolvimento territorial e sustentabilidade}

$\mathrm{Na}$ concepção de desenvolvimento territorial aqui referida, ressalta-se a importância dos recursos e ativos materiais e imateriais nos processos de mudança de uma sociedade organizada territorialmente. Mas resta ainda uma ressalva: mesmo que se entenda que um processo de desenvolvimento precisa, necessariamente, contemplar a dimensão da sustentabilidade ambiental, talvez seja necessário esclarecer do que se está falando quando nos referimos ao desenvolvimento sustentável.

Assume-se a concepção de sustentabilidade expressa no relatório da Comissão Mundial sobre o Meio Ambiente e Desenvolvimento (CMmAD, 1988, p. 46): "O desenvolvimento sustentável é aquele que atende às necessidades do presente sem comprometer a possibilidade das geraçóes futuras atenderem as suas próprias necessidades". Nesta concepção de sustentabilidade estão referidas duas questóes-chave: necessidades e limitação. Estes são parâmetros importantes a serem observados, com o que a sociedade humana é convidada a pensar e distinguir as reais necessidades 
para sobreviver, considerando as noçóes dos limites ou limitaçóes da natureza físico-natural.

Neste estudo serão consideradas quatro dimensões em relação à sustentabilidade como elementos indicativos na observação das experiências de especificação de ativos territoriais estudadas, quais sejam, o social, o ambiental, o cultural e o econômico.

As perspectivas de criação de riquezas nos territórios estão relacionadas às capacidades dos grupos quanto à organização e à elaboração de processos originais de emergência de recursos (Benko \& Pecqueur, 2001). O fato de um território assumir os princípios da sustentabilidade ambiental no seu projeto de desenvolvimento futuro parece de fundamental importância, pois agregaria mais elementos distintivos à identidade territorial da região.

Qual a importância e quais as perspectivas desta situação positiva vir a ocorrer? Albagli (2004) faz consideraçóes que contribuem para a resposta à questão colocada. A autora chama a atenção que a sustentabilidade do desenvolvimento pode estar ancorada na noção de território. No entanto, a apreciação do território unicamente a partir da sua capacidade de atrair investimentos e de gerar lucratividade tende a consumir de forma predatória os recursos tanto naturais, quanto sociais e culturais. Em contrapartida, o desenvolvimento local tendo como suporte a noção de território tende a estimular os laços de identificação e solidariedade, garantindo no longo prazo melhores condiçóes de sustentabilidade. Dentre outros, esses argumentos justificam a hipótese de trabalho que motivou a realização do presente estudo.

\section{O debate conceitual sobre governança}

A introduçáo do tema governança se justifica pelo fato de que o presente estudo se propóe avaliar a contribuição do sistema de governança territorial na sustentabilidade de experiências de especificação de ativos territoriais.

Faz-se referência apenas a algumas obras, em específico, sobre governança territorial ${ }^{2}$. Em síntese, autores assim a definem: (1) processo de planejamento e gestão de dinâmicas territoriais, numa ótica inovadora, partilhada e colaborativa, por meio de relações voluntárias e não hierárquicas de associação entre atores públicos, semipúblicos e privados (Ferrão, 2010 e 2013); (2) novo modo de gestão e decisão dos assuntos públicos num território, como modalidade reforçada de bom governo, fundamentada num papel insubstituível do Estado, uma concepção mais sofisticada de democracia e um maior protagonismo da sociedade civil (Farinós, 2008; Romero \& Farinós, 2011).

Sobre governança territorial se assume um posicionamento referenciado em Dallabrida (2015), e que representa uma síntese das referências anteriores.

A governança territorial corresponde a um processo de planeamento [planejamento] e gestão de dinâmicas territoriais que dá prioridade a uma ótica inovadora, partilhada e colaborativa, por meio de relaçôes horizontais. No entanto, esse processo inclui lutas de poder, discussóes, negociaçóes e, por fim, deliberaçóes, entre agentes estatais, representantes dos setores sociais e empresariais, de centros universitários ou de investigação. (p. 325)

Para aprofundamento do tema governança e governança territorial, ver: Dallabrida (2015). 
Ressalta-se que processos desta natureza se fundamentam “(...) num papel insubstituível do Estado, numa noção qualificada de democracia, e no protagonismo da sociedade civil, objetivando harmonizar uma visão sobre o futuro e um determinado padrão de desenvolvimento territorial" (Dallabrida, 2015, p. 325). Por fim, processos assim caracterizados, além de servirem de parâmetro, tem como fim o desenvolvimento territorial.

\section{Situando a questáo da especificação de ativos territoriais e suas formas de governança}

Ao se tratar conjuntamente as experiências de especificação de ativos territoriais no Brasil e Portugal, é indispensável lembrar que há uma diferença expressiva entre a quantidade de produtos e o teor das normas. Assim mesmo a opçáo em eleger experiências dos dois países, deveu-se à oportunidade da realizaçáo de estudos de estudos em Portugal, em $2013^{3}$.

Dados de 2011 indicam a existência, nos países da União Europeia, de 1.035 produtos com certificação, dentre Denominaçôes de Origem Protegida (DOP), Indicaçôes Geográficas Garantidas (IGP) e Especialidades Tradicionais Garantidas (ETG). Se a esses dados agregarmos as 1.334 Dop ou Denominaçóes de Origem Controlada (DOC) e 587 IGP de vinhos, chegaremos a um universo de quase 3.000 produtos regis-

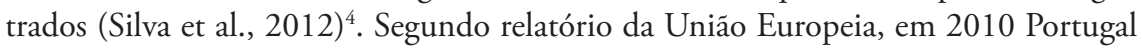
contava com 170 produtos certificados, sendo 59 do setor vitivinícola ${ }^{5}$.

No Brasil a certificação de produtos com especificidade territorial é feita via a Indicação Geográfica. Esta consiste em duas modalidades: a Indicação de Procedência e a Denominação de Origem. A Indicação de Procedência (IP) faz referência ao nome geográfico de um país, cidade, região ou território, que se tornou conhecido como centro de produção, fabricação ou extração de determinado produto ou prestação de serviço. Já a Denominação de Origem (Do) é o nome geográfico de um país, cidade, regiāo ou território que designe produto ou serviço cujas qualidades ou características se devam exclusiva ou essencialmente ao meio geográfico específico, incluídos fatores naturais e humanos. Assim, a diferença singular entre as formas de Indicação Geográfica está associada às características e peculiaridades físicas e humanas potencializadas pelo território ${ }^{6}$.

No Brasil, até dezembro de 2015 estavam registradas 53 experiências de Indicação Geográfica, sendo 45 nacionais e 8 estrangeiras. Das nacionais, 36 são na espécie Indicação de Procedência e 9 como Denominação de Origem. Todas as estrangeiras são registradas como Denominação de Origem $^{7}$.

Trata-se de estudos realizados pelo autor do texto no Instituto de Ciências Sociais da Universidade de Lisboa, em 2013.

4 Outras duas obras recentes fazem uma descriçấo da realidade brasileira em relação ao tema, comparativamente com países europeus: Froehlich (2012); Sacco dos Anjos e Caldas (2010).

5 Fonte: http://ec.europa.eu/agriculture/external-studies/2012/value-gi/final-report_en.pdf

6 Conf. Lei 9.279, de 14/05/1996 e Resoluçấo Instituto Nacional de Propriedade Industrial (INPI) $75 / 2000$.

7 Dados extraídos do site do Instituto Nacional de Propriedade Industrial (INPI): http://www.inpi.gov.br/ menu-servicos/indicacao-geografica/pedidos-de-indicacao-geografica-no-brasil. Acesso em 01/12/2015. 
Em Portugal, destaca-se a quantidade de vinhos com certificação, identificados pela sua região de produção. Para os vinhos se utiliza a designação Denominação de Origem Protegida para os produtos vitivinícolas cuja originalidade e individualidade estão ligadas de forma indissociável a uma determinada regiáo, local ou denominação tradicional, e cujas qualidades ou características específicas são devidas ao meio geográfico, fatores naturais e humanos. Estes produtos estão sujeitos a regras específicas de controle que visam garantir a autenticidade e qualidade e podem ser rotulados como Denominação de Origem Controlada. Já a Indicação Geográfica Protegida é a designação adotada para os vinhos de uma região específica cujo nome adota na rotulagem, elaborados com pelo menos $85 \%$ de uvas provenientes dessa regiáo. Tal como os produtos com DOP/DOC, são sujeitos a regras específicas de controle. Estes vinhos normalmente são rotulados como Vinho Regional.

Os demais produtos certificados, sejam de origem agrícola ou animal, são designados como DOP ou IGP. Já os produtos designados como ETG não estão vinculados a uma origem específica, correspondendo a um produto agrícola ou gênero alimentício produzido a partir das matérias-primas tradicionais, ou com uma composição tradicional ou um modo de produção e/ou de transformação tradicional que o distinga de outros produtos similares. Sáo distinguidos também produtos cultivados de forma agroecológica.

Em relação à situação das IGs e DOC / DOP, os processos de governança territorial em experiências com produtos sustentados na identidade territorial articulam comportamentos dos indivíduos e do ambiente institucional, caracterizando-se num processo dinâmico envolvido na formulação e resolução de problemas produtivos, amparado na existência de um compromisso institucional (Ex. a normatização que regula a forma de produção e o padrão de qualidade dos produtos), que envolve atores econômicos e públicos (Pecqueur, 2000), ou seja, estamos diante de um tipo complexo de governança. Por este e outros motivos, as formas de estruturação da governança para a sustentação das experiências, torna-se um elemento significativo de análise. Neste sentido, Flores (2006) chega a afirmar que tais estruturas respondem por parte do sucesso das iniciativas de valorização de produtos com base na identidade territorial.

\section{Procedimentos metodológicos e caracterizaçáo da amostra investigada}

O estudo das experiências de governança territorial em áreas de Indicação Geográfica (Brasil) e de Denominaçóes de Origem Controlada ou Protegida (Portugal) contemplou vários procedimentos metodológicos: (a) análise bibliográfica; (b) consulta documental; (c) visitação de experiências; (d) entrevistas com atores chave, tomando por base questóes semiestruturadas que buscavam informaçóes sobre o histórico da experiência, sua estrutura organizacional e de funcionamento, principais potencialidades e limites, iniciativas previstas para a superação dos desafios, resultados alcançados e seu impacto no desenvolvimento do território atingido; (e) realização de um inquérito por questionário a cinco atores de cada experiência, com questóes que tinham como propósito avaliar aspectos relativos à qualidade das práticas de governança territorial. 
O questionário utilizado na pesquisa foi elaborado tomando por base a concepção sobre governança ou governança territorial de um conjunto de autores, tendo sido destacados os componentes analíticos considerados princípios fundantes de práticas qualificadas de governança territorial. $\mathrm{O}$ quadro 1 sintetiza tais componentes analíticos, na forma de dimensóes, categorias conceituais e critérios.

\section{QUADRo 1 | Dimensóes, categorias e critérios para avaliação de práticas de governança territorial}

\begin{tabular}{|c|c|c|c|}
\hline DIMENSÓES & $\mathbf{N}^{\mathbf{o}}$ & CATEGORIAS & CRITÉRIOS \\
\hline \multirow{7}{*}{$\begin{array}{l}\text { A- Atores, } \\
\text { poderes e } \\
\text { relaçóes }\end{array}$} & 1 & $\begin{array}{l}\text { Subsidiariedade (vertical e } \\
\text { horizontal) }\end{array}$ & Repartição de atribuiçóes e competências \\
\hline & 2 & Relacionalidade & Integração relacional com o outro \\
\hline & 3 & Liderança & Liderança descentrada e compartilhada \\
\hline & 4 & Protagonismo estatal & Proeminência do Estado, como orientador das redes \\
\hline & 5 & Protagonismo social & Participação ativa da sociedade civil \\
\hline & 6 & Protagonismo empresarial & Ação empresarial responsável socioambientalmente \\
\hline & 7 & Resiliência & $\begin{array}{l}\text { Resistência X maleabilidade de atores e instituiçóes em } \\
\text { face das mudanças }\end{array}$ \\
\hline \multirow{7}{*}{$\begin{array}{l}\text { B- Processos } \\
\text { de decisāo }\end{array}$} & 8 & Representatividade & Representatividade dos membros dos setores \\
\hline & 9 & Ancoragem democrática & Democratização das decisões \\
\hline & 10 & Reciprocidade & $\begin{array}{l}\text { Responsabilidade coletiva, com contribuição das } \\
\text { partes para fins comuns }\end{array}$ \\
\hline & 11 & $\begin{array}{l}\text { Cooperaçáo e Interdepen- } \\
\text { dência }\end{array}$ & $\begin{array}{l}\text { Gestáo de conflitos, com a legitimação das açóes pela } \\
\text { cooperaçáo, negociação e partilhamento }\end{array}$ \\
\hline & 12 & Transparência & $\begin{array}{l}\text { Limpidez, processos e formas de comunicação } \\
\text { acessíveis, supervisão e fiscalização }\end{array}$ \\
\hline & 13 & Reflexibilidade & $\begin{array}{l}\text { Capacidade de refletir, analisar e revisar rotinas, } \\
\text { tecnologias, processos e resultados }\end{array}$ \\
\hline & 14 & Governabilidade & Posse de capacidade de governar em rede \\
\hline \multirow{4}{*}{$\begin{array}{l}\text { C- Coor- } \\
\text { denaçáo de } \\
\text { Políticas }\end{array}$} & 15 & $\begin{array}{l}\text { Descentralização de } \\
\text { políticas }\end{array}$ & $\begin{array}{l}\text { Supervisão estratégica para permitir a agregação de } \\
\text { áreas e setores de políticas relevantes }\end{array}$ \\
\hline & 16 & Integração horizontal & $\begin{array}{l}\text { Integração intersistêmica entre as políticas com impac- } \\
\text { to no território }\end{array}$ \\
\hline & 17 & Integração vertical & $\begin{array}{l}\text { Integração das políticas de cunho verticalizado, } \\
\text { oriundas das diferentes instâncias de governo }\end{array}$ \\
\hline & 18 & Eficácia das políticas & Foco dos resultados nos objetivos definidos coletivamente \\
\hline \multirow{6}{*}{$\begin{array}{l}\text { D- Resul- } \\
\text { tado dos } \\
\text { Processos de } \\
\text { Governança } \\
\text { Territorial }\end{array}$} & 19 & Atendimento da pluralidade & $\begin{array}{l}\text { Abrangência da variedade de interesses, crenças, } \\
\text { tradiçôes e dilemas }\end{array}$ \\
\hline & 20 & $\begin{array}{l}\text { Compartilhamento de } \\
\text { objetivos e metas }\end{array}$ & $\begin{array}{l}\text { Maximização dos efeitos das políticas na sociedade e } \\
\text { nos territórios }\end{array}$ \\
\hline & 21 & Aprendizagem interativa & Interação e aprendizagem coletiva \\
\hline & 22 & $\begin{array}{l}\text { Empoderamento dos } \\
\text { atores }\end{array}$ & Atores como sujeitos da ação coletiva \\
\hline & 23 & $\begin{array}{l}\text { Territorialização dos pro- } \\
\text { cessos de desenvolvimento }\end{array}$ & $\begin{array}{l}\text { Território como matriz de referência, com potenciaçáo } \\
\text { do capital territorial, sem desconsiderar a } \\
\text { multiescalaridade dos processos }\end{array}$ \\
\hline & 24 & Gestão territorial integrada & $\begin{array}{l}\text { Foco na melhoria da coesão social e no desenvolvi- } \\
\text { mento socioeconômico-ambiental }\end{array}$ \\
\hline
\end{tabular}

FONTE ELABORAÇÃO PRÓPRIA COM BASE NA PESQUISA 
Foram analisadas dez experiências, sendo cinco no Brasil e cinco em Portugal. Para todas elas foram consultados documentos e informaçóes disponíveis. Em nove casos foi realizada a visitação, observando a experiência e entrevistando pessoalmente os atores-chave. $\mathrm{O}$ inquérito por questionário foi aplicado em seis experiências, três no Brasil e três em Portugal. No quadro 2 são caracterizadas as experiências, com sua tipificação, procedimento metodológico aplicado e localização.

QUADRO 2 | Experiências pesquisadas de DOC/DOP (Portugal) e de IG (Brasil)

\begin{tabular}{|c|c|c|c|c|c|c|c|}
\hline \multirow{2}{*}{$\mathbf{N}^{\mathbf{o}}$} & \multirow{2}{*}{$\begin{array}{l}\text { TIPIFICAÇÃO DAS } \\
\text { EXPERIÊNCIAS }\end{array}$} & \multicolumn{4}{|c|}{$\begin{array}{l}\text { PROCEDIMENTO METODOLÓGICO } \\
\text { APLICADO }\end{array}$} & \multicolumn{2}{|c|}{ LOCALIZAÇÃO } \\
\hline & & VISITAÇÃO & ENTREVISTA & INQUÉRITO & $\begin{array}{l}\text { PESQUISA } \\
\text { D. }\end{array}$ & BRASIL & PORTUGAL \\
\hline 1 & $\begin{array}{l}\text { IG de vinhos e espumantes } \\
\text { tradicionais }\end{array}$ & $\mathrm{X}$ & $\mathrm{X}$ & $\mathrm{X}$ & $\mathrm{X}$ & & $\mathrm{X}$ \\
\hline 2 & $\begin{array}{l}\text { IG de vinho de tipo } \\
\text { específico de uva }\end{array}$ & $\mathrm{X}$ & $\mathrm{X}$ & $\mathrm{X}$ & $\mathrm{X}$ & & $\mathrm{X}$ \\
\hline 3 & $\begin{array}{l}\text { IG de própolis típico de } \\
\text { abelha }\end{array}$ & $\mathrm{X}$ & $\mathrm{X}$ & $\mathrm{X}$ & $\mathrm{X}$ & & $\mathrm{X}$ \\
\hline 4 & $\begin{array}{l}\text { IG de artesanato típico de } \\
\text { barro }\end{array}$ & $\mathrm{X}$ & $\mathrm{X}$ & & $\mathrm{X}$ & & $\mathrm{X}$ \\
\hline 5 & IG de aguardente de cana & $\mathrm{X}$ & $\mathrm{X}$ & & $\mathrm{X}$ & & $\mathrm{X}$ \\
\hline 6 & Doc de vinho tradicional & $\mathrm{X}$ & $\mathrm{X}$ & $\mathrm{X}$ & $\mathrm{X}$ & $\mathrm{X}$ & \\
\hline 7 & Doc de vinho típico & $\mathrm{X}$ & & & $\mathrm{X}$ & $\mathrm{X}$ & \\
\hline 8 & Dop de queijo típico & $\mathrm{X}$ & $\mathrm{X}$ & & $\mathrm{X}$ & $\mathrm{X}$ & \\
\hline 9 & $\begin{array}{l}\text { Dop de produtos de origem } \\
\text { animal-1 }\end{array}$ & $\mathrm{X}$ & & $\mathrm{X}$ & $\mathrm{X}$ & $\mathrm{X}$ & \\
\hline 10 & $\begin{array}{l}\text { DOp de produtos de origem } \\
\text { animal-2 }\end{array}$ & & & $\mathrm{X}$ & $\mathrm{X}$ & $\mathrm{X}$ & \\
\hline
\end{tabular}

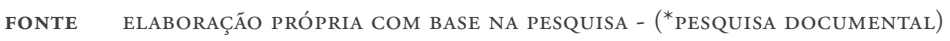

\section{Análise dos resultados}

Divide-se a análise dos resultados das experiências pesquisadas em quatro aspectos: (a) questôes de ordem geral, referentes às experiências observadas no Brasil e Portugal; (b) observaçóes específicas das experiências brasileiras e portuguesas, relacionadas às dimensóes ambiental, social, cultural e econômica; (c) questôes gerais referentes à estrutura de governança territorial das experiências pesquisadas; (d) análise da qualidade das práticas de governança territorial.

Questóes de ordem geral referentes às experiências observadas (Brasil e Portugal) Em primeiro lugar, observaçóes feitas no estudo de experiências de especificação de ativos territoriais de Portugal (DOC/DOP) e do Brasil (IP/DO) permitem questionar a eficácia da proliferação das figuras de proteção e certificação de produtos. Esta situação, em geral, resulta em dificuldades por parte dos consumidores em avaliar as singularidades e os diferenciais de qualidade dos produtos protegidos ${ }^{8}$.

8 Tal afirmação coincide com análises relatadas em Sacco dos Anjos e Caldas (2010) e Silva et al. (2012). 
Nas visitas de experiências de DOC e Dop de Portugal verificou-se que da produção total apenas parte vai para o mercado com o selo de certificaçáo, demonstrando que, mesmo em países europeus com uma tradição de produtos certificados que excede os 100 anos, observa-se que o consumo de produtos diferenciados ainda náo é massivo. Esta situação é muito mais significativa no Brasil, onde a certificação de produtos, no caso, na forma de IP ou DO, ocorre apenas a partir dos últimos 20 anos. Mesmo considerando diferenças nas dimensôes, o motivo alegado é o mesmo: poucos consumidores ainda tomam como referência para o consumo a questão da certificação. Isso remete à necessidade de estratégias de divulgação diferenciadas daquelas já utilizadas, e que apresentem maior eficácia.

\section{Análise das experiências brasileiras}

Com base na visitação e estudo de cinco experiências de IG's brasileiras, foram percebidos aspectos positivos e desafios de diferentes ordens. No quadro 3 estão destacadas as questóes mais significativas, considerando as respostas dos entrevistados.

\section{QUADRO 3 | Tipificação das experiências e observaçóes em relação às dimensóes} da sustentabilidade

\begin{tabular}{|c|c|}
\hline DIMENSÃO & RESUMO DAS OBSERVAÇÓES REALIZADAS \\
\hline \multicolumn{2}{|l|}{$\begin{array}{l}\text { Experiência } 1 \text { - Produção } \\
\text { de aguardente de cana de } \\
\text { açúcar }\end{array}$} \\
\hline Social & $\begin{array}{l}\text { Atende apenas sete produtores e náo se trata de atividade de alta emprega- } \\
\text { bilidade }\end{array}$ \\
\hline Ambiental & $\begin{array}{l}\text { Apenas recentemente, começou a preocupação com questóes de preser- } \\
\text { vação ambiental e dos solos, havendo ainda utilizaçáo de agrotóxicos na } \\
\text { produção agrícola }\end{array}$ \\
\hline Cultural & $\begin{array}{l}\text { Resgata, valoriza e potencializa a cultura e tradição histórica de produção } \\
\text { local, havendo uma associação entre a marca do produto e a cidade em que } \\
\text { é produzido }\end{array}$ \\
\hline Econômica & $\begin{array}{l}\text { Atividade econômica viável, que impacta positivamente sobre o turismo } \\
\text { e demais atividades locais e regionais; no entanto, parte da matéria-prima } \\
\text { ainda é importada de outras regióes, restringindo a geraçáo de renda e } \\
\text { emprego localmente }\end{array}$ \\
\hline \multicolumn{2}{|l|}{$\begin{array}{l}\text { Experiência } 2 \text { - Produtos } \\
\text { de artesanato e de utilidade } \\
\text { doméstica a partir da argila } \\
\text { natural }\end{array}$} \\
\hline Social & $\begin{array}{l}\text { Forte inclusão social, com geração de emprego e renda às famílias da perife- } \\
\text { ria urbana }\end{array}$ \\
\hline Ambiental & $\begin{array}{l}\text { Grande preocupaçáo com a questấo da preservaçáo ambiental, havendo, no } \\
\text { entanto, risco de esgotamento da matéria-prima (argila) no longo prazo }\end{array}$ \\
\hline Cultural & $\begin{array}{l}\text { Atividade ancorada nos saberes ancestrais, preservando sua originalidade, } \\
\text { no entanto, há o risco de outras experiências reproduzirem estratégias } \\
\text { semelhantes }\end{array}$ \\
\hline Econômica & $\begin{array}{l}\text { Atividade permite renda mínima para o sustento das famílias envolvidas, } \\
\text { tendo forte marketing de mercado, no entanto, opera ainda com baixo } \\
\text { preço de venda, impossibilitando uma rentabilidade financeira mais } \\
\text { significativa }\end{array}$ \\
\hline
\end{tabular}


(continuação)

\begin{tabular}{|c|c|}
\hline DIMENSÃO & RESUMO DAS OBSERVAÇÓES REALIZADAS \\
\hline \multicolumn{2}{|l|}{$\begin{array}{l}\text { Experiência } 3 \text { - Produção } \\
\text { de própolis diferenciada a } \\
\text { partir da apicultura local }\end{array}$} \\
\hline Social & $\begin{array}{l}\text { Viabiliza socioeconomicamente os envolvidos, no entanto, há uma baixa } \\
\text { adesão ao associativismo, devido às experiências frustradas, estimulando } \\
\text { estratégias individualizadas }\end{array}$ \\
\hline Ambiental & $\begin{array}{l}\text { Atividade sustentável ambientalmente; produz alimento que contribui na } \\
\text { promoçáo da saúde humana, com propriedades medicinais }\end{array}$ \\
\hline Cultural & $\begin{array}{l}\text { O envolvimento na atividade cria relaçóes de apego com o meio natural, } \\
\text { havendo uma consciência de valorização das características específicas do } \\
\text { produto }\end{array}$ \\
\hline Econômica & $\begin{array}{l}\text { Atividade lucrativa, tendo conquistado o mercado nacional e interna- } \\
\text { cional, impactando positivamente na economia local; há a preocupaçáo } \\
\text { em capitalizar vantagens localmente, avançando tecnologicamente na } \\
\text { industrializaçáo }\end{array}$ \\
\hline \multicolumn{2}{|l|}{$\begin{array}{l}\text { Experiência } 4 \text { - Produção } \\
\text { de vinhos a partir de tipo } \\
\text { específico de uva }\end{array}$} \\
\hline Social & $\begin{array}{l}\text { É uma atividade inclusiva, tendo potencial para ampliar a participação } \\
\text { de novos associados; caracteriza-se pela forte mobilização da sociedade } \\
\text { municipal e regional }\end{array}$ \\
\hline Ambiental & $\begin{array}{l}\text { Trata-se de atividade de baixo risco ambiental, no entanto, poderia haver } \\
\text { avanços no cultivo da uva, por exemplo, reduzindo ou eliminando o uso de } \\
\text { agrotóxicos }\end{array}$ \\
\hline Cultural & $\begin{array}{l}\text { Atividade contribui no resgate e valorização da cultura dos anteceden- } \\
\text { tes (imigrantes colonizadores), preservando e difundindo saberes entre } \\
\text { geraçôes (passado e presente) }\end{array}$ \\
\hline Econômica & $\begin{array}{l}\text { Atividade viável economicamente, porém ainda com limitaçóes no mer- } \\
\text { cado de consumo; tem potencial para a dinamização de outras atividades } \\
\text { econômicas }\end{array}$ \\
\hline \multicolumn{2}{|l|}{$\begin{array}{l}\text { Experiência } 5 \text { - Produção } \\
\text { de vinhos e espumantes } \\
\text { diferenciados }\end{array}$} \\
\hline Social & $\begin{array}{l}\text { Tem potencial de ampliar as condições de inclusão social, pois, no momen- } \\
\text { to envolve poucos proprietários e empresas locais }\end{array}$ \\
\hline Ambiental & $\begin{array}{l}\text { Trata-se de atividade de baixo risco ambiental, no entanto, poderia diferen- } \\
\text { ciar-se, qualificando-se pela nấo utilizaçáo de agrotóxicos na produçáo }\end{array}$ \\
\hline Cultural & $\begin{array}{l}\text { Agrega saberes geracionais de tradição local, associando a produção com a } \\
\text { preservaçáo de traços culturais históricos }\end{array}$ \\
\hline Econômica & $\begin{array}{l}\text { É uma atividade economicamente viável, possuindo mercado consumidor } \\
\text { nacional consolidado, no entanto, precisa avançar, com estratégias de } \\
\text { ampliaçáo do consumo }\end{array}$ \\
\hline
\end{tabular}

FONTE ELABORAÇÃo PRÓPRIA

Sintetizando, ao analisar experiências brasileiras podem ser destacados como principais desafios os seguintes: (a) reduzido número de sócios nas IG's, o que denota baixa capacidade de inclusão social; (b) as IG`s, em geral, são negócios lucrativos privados que utilizam a estratégia do associativismo para se viabilizarem, talvez, mais por exigência legal do que por convicção de necessidade; (c) nas experiências agrícolas, é percebida a falta de mão de obra não especializada; (d) há reconhecimento unânime dos entrevistados de que a população pouco conhece o que é uma IG, o que implica em limitaçóes no mercado de consumo; (e) necessidade de ampliação do marketing dos produtos; (e) carência de uma cultura solidária e de associativismo; 
(f) baixa preocupação com as questôes ambientais e as possibilidades de produção sustentável ambientalmente; (g) o impacto econômico das IG`s pode ser ampliado, se considerar atividades potenciais, entre elas o turismo, além da integração com as demais atividades econômicas; (h) por fim, a especificação de ativos territoriais como estratégia de desenvolvimento se apresenta como uma possibilidade, não a única. No entanto, para não fazer referência apenas aos desafios, ressaltamos que, de maneira geral, percebe-se nos territórios com IG`s a valorização da identidade cultural, além de maior dinamismo socioeconômico.

\section{Análise das experiências portuguesas}

Em relação às experiências de Portugal, alguns dos desafios coincidem com os destacados nas experiências brasileiras, com relevo para a questão da carência de uma cultura solidária e de associativismo e o fato de que, na verdade, trata-se de negócios lucrativos privados que utilizam a estratégia do associativismo para se viabilizarem. Ao alertar sobre esta situação, náo se está emitindo qualquer juízo de valor, positivo ou negativo. Trata-se apenas de uma constatação, pois tal situação será favorável para umas finalidades e interesses e desfavorável para outros.

Quanto à tipologia das experiências visitadas em Portugal, tem-se a seguinte situaçáo: duas relacionadas à vitivinicultura em regióes portuguesas tradicionais na produção de vinho; uma relacionada à produção de queijos especiais; outras duas relacionadas ao beneficiamento de produtos de origem animal com especificidade.

\section{a) Questóes relacionadas à dimensáo social}

Com base nas experiências analisadas na produção de vinhos, de queijo e produtos de origem animal, é possível observar que são estruturadas sob a forma de comissóes nacionais, ou associaçóes, que articulam a produção quanto ao apoio técnico, normatizaçóes legais, regulação do volume da produção, inserção dos produtos no mercado e marketing geral, principalmente no setor industrial. Portanto, as relaçóes de trabalho regem-se pelos padróes próprios do sistema empresarial moderno. Já o setor de produção da matéria prima (a uva, o leite e animais) compreende tanto produtores e criadores isolados como organizaçóes empresariais. Alguns setores agregam mão de obra sazonalmente, como na produção de vinho. Em certas regióes, tais atividades são as que mais empregam.

\section{b) Questóes relacionadas à dimensão ambiental}

Em geral, as atividades produtivas analisadas não têm impactos ambientais significativos. Já há alguns anos existe a preocupação com questóes de preservação ambiental, no entanto, ainda é pouco significativa a produção sustentável ambientalmente, havendo ainda utilização de agroquímicos no processo produtivo e industrial. O caso mais emblemático, em que o processo produtivo tem uma relaçáo equilibrada com o meio ambiente, é o da produção de animais autóctones. Sáo raças rústicas, menos exigentes em instalaçóes, cuidados alimentares e quanto à sanidade. Trata-se de um sistema de produçáo extensiva, em campos abertos, alimentando-se de ervas e frutos silvestres, restos de colheitas agrícolas, complementada com cereais e raçóes compostas. 


\section{c) Questốes relacionadas à dimensão cultural}

Das experiências visitadas, cabe um destaque inicial à produção vitivinícola. O setor mantém uma relação de identidade com a tradição histórica centenária na produção de vinhos. Por isso há uma forte relação de identidade da região com tais tradiçôes, o que leva a manter ativas festividades que marcam as fases de produção vinícola, como o exemplo da vindima (período de colheita). Além das festividades, a tradição é mantida também pela preservação da memória arquitetônica e histórico-cultural, por exemplo, com a presença de museus. No entanto, é possível observar que se mantém viva a relação de identidade com sua história, predominantemente, como estratégia de marketing para divulgação dos produtos e como atração turística.

Outro caso de destaque é a produção de animais autóctones. Trata-se da preservação de formas de criação do passado, quando ainda não havia a introdução de melhoramento genético no setor. Já no caso do queijo, resgata-se e mantém-se uma tradição de atividade quase única em algumas regiōes, em função de restriçóes locais de ordem físico-natural, pois é uma atividade historicamente realizada em regiōes de vegetação rasteira e solos pouco aproveitáveis para atividades agrícolas, semelhantes às savanas, em geral com baixa pluviosidade em boa parte do ano.

\section{d) Questóes relacionadas à dimensáo econômica}

Mesmo que parte do processo produtivo ocorra sob a forma de produção familiar, com destaque para o caso do queijo, estamos nos referindo a atividades inseridas no circuito da produçáo industrial e comercial nacional e internacional. Em especial o vinho, trata-se de um produto de tradição em Portugal, o qual representa um percentual significativo das suas exportaçóes. Portanto, trata-se de atividades inseridas na lógica de mercado, tendo assim necessidade de ser competitivas tecnologicamente e em termos de qualidade e preço.

\section{Questóes referentes à estrutura de governança territorial dos dois países}

Nas experiências brasileiras, nas quais o estudo pode ser feito de uma forma mais aprofundada, foram constatadas dificuldades de produtores, artesãos ou empresários em trabalhar e se relacionar associativamente, situação relacionada com níveis significativos de centralização de poder, vaidades e interesses individualistas, em detrimento de conquistas coletivas. Questóes semelhantes, no entanto com diferentes dimensôes e características, puderam também ser observadas nas experiências em Portugal. Por exemplo, uma experiência de Dop visitada iniciou como cooperativa agrícola, a qual recentemente foi fechada, sendo agora operacionalizada por meio de empresas individuais.

Em relação à estrutura de governança de produtos com especificidade territorial, no Brasil há constrangimentos de ordem legal e prática, principalmente, no que se refere à criação de estruturas destinadas à comercialização coletiva do produto certificado territorialmente. $\mathrm{Na}$ unanimidade, no Brasil, as experiências visitadas apresentaram este desafio, pois são estruturadas na forma de associações, as quais legalmente não estão habilitadas a operar comercialmente no mercado. Perguntavam-se alguns entrevistados: seria o caso de constituir uma cooperativa para a comercialização coletiva? No entanto, outros argumentavam esta não ser a 
alternativa adequada, pelo fato de ter impedimento legal de associarem-se a uma mesma cooperativa, juntamente, produtores individuais e empresas. Sáo questóes que precisam ser aprofundadas, criando os instrumentos legais adequados para sua operacionalização.

No caso de Portugal este problema é resolvido, ao menos em parte, em alguns casos pela constituição de cooperativas encarregadas da industrialização ou comercialização. Em outros casos, há a estruturação de associaçôes nacionais e, no caso do vinho, as comissóes vitivinícolas regionais. Tais associaçôes, ou comissóes, assumem o papel de assessorar tecnicamente a atividade, além da promoção comercial, nacional e internacional. $\mathrm{O}$ processo de industrialização e comercialização é feito pelas empresas, individualmente.

Há em Portugal, comparativamente com o Brasil, um maior profissionalismo comercial nas atividades produtivas com produtos certificados. Assim, é possível que alguns avanços já obtidos em Portugal possam, no futuro, ser readequados para as experiências de IG's brasileiras, mesmo que, em algumas situaçôes, sejam necessárias mudanças na legislação.

\section{Análise da qualidade das práticas de governança territorial}

A análise dos inquéritos aplicados com atores das experiências de DOC/DOP em Portugal e de IP/Do no Brasil permite fazer algumas observaçôes. As análises levam em conta o resultado da aplicação de um inquérito em seis experiências, no Brasil e Portugal, atingindo uma amostra de dezoito atores, entre dirigentes, técnicos e assessores, representantes dos setores sociais, empresariais e públicos. Dos trinta questionários enviados, conseguimos um retorno de 60\%. Mesmo que o universo da amostra possa ser considerado relativamente pequeno, é um indicativo com alguma significância.

A opção de resposta permitia quatro alternativas: discordância total e parcial (1 e 2); concordância parcial e total (3 e 4). A avaliação feita pelos atores inquiridos, tanto nas experiências brasileiras como nas portuguesas é predominantemente positiva. No quadro 4 está um resumo das respostas dos inquiridos, apresentando os percentuais de respostas de discordância, as quais permitem inferências quanto às características das práticas de governança territorial analisadas.

Analisada a situação apenas por estas informaçôes estatísticas, tem-se uma situação favorável quanto à governança territorial, considerando a percepçáo dos atores envolvidos nas experiências. Apenas em sete dos vinte e oito princípios definidos, o grau de discordância é significativo, isto é, acima de 25\%. A análise se deterá mais nestes elementos.

Os princípios que foram avaliados como predominantemente negativos são (pela ordem decrescente): Protagonismo Estatal (Estado como articulador principal das redes); Integração Vertical (integração das políticas oriundas das diferentes instâncias de governo no território); Resiliência (resistência ou maleabilidade de atores e instituiçôes em face das mudanças); Eficácia das Políticas (foco dos resultados e nos objetivos definidos coletivamente); Protagonismo Social (participaçáo ativa da sociedade civil); Liderança (descentralizada e partilhada); Integração Horizontal (integração intersistêmica entre as políticas com impacto no território). 
QUADRo 4 | Percentual (\%) de respostas de discordância (1 e 2), nos inquéritos do Brasil e Portugal

\begin{tabular}{|c|c|c|c|c|c|c|c|}
\hline \multicolumn{8}{|c|}{ DIMENSÁO A - ATORES, PODERES E RELAÇÓES } \\
\hline & $\begin{array}{c}\text { Subsidiarie- } \\
\text { dade }\end{array}$ & Interação & Liderança & Pró-Estado & Pró-Social & Pró-Empresa & Resiliência \\
\hline Percentual & $22 \%$ & $11 \%$ & $28 \%$ & $56 \%$ & $28 \%$ & $17 \%$ & $34 \%$ \\
\hline \multicolumn{8}{|c|}{ DIMENSÃO B - PROCESSOS DE DECISÃO } \\
\hline & $\begin{array}{c}\text { Representa- } \\
\text { tividade }\end{array}$ & Democracia & $\begin{array}{l}\text { Reciproxi- } \\
\text { dade }\end{array}$ & $\begin{array}{c}\text { Interdepen- } \\
\text { dência }\end{array}$ & $\begin{array}{l}\text { Transpa- } \\
\text { rência }\end{array}$ & $\begin{array}{c}\text { Reflexibili- } \\
\text { dade }\end{array}$ & $\begin{array}{c}\text { Govenabili- } \\
\text { dade }\end{array}$ \\
\hline Percentual & $0 \%$ & $5 \%$ & $5 \%$ & $17 \%$ & $0 \%$ & $11 \%$ & $5 \%$ \\
\hline \multicolumn{8}{|c|}{ DIMENSÁO C - COORDENAÇÃO DE POLÍTICAS } \\
\hline & $\begin{array}{c}\text { Descentra- } \\
\text { lizaçấo }\end{array}$ & $\begin{array}{l}\text { Integraçáo } \\
\text { Horizontal }\end{array}$ & $\begin{array}{c}\text { Integração } \\
\text { Vertical }\end{array}$ & $\begin{array}{l}\text { Eficácia das } \\
\text { Políticas }\end{array}$ & & & \\
\hline Percentual & $5 \%$ & $28 \%$ & $39 \%$ & $34 \%$ & & & \\
\hline \multicolumn{8}{|c|}{ DIMENSÃO D - RESULTADO DOS PROCESSOS DE GOVERNANÇA TERRITORIAL } \\
\hline & Pluralidade & $\begin{array}{c}\text { Partilha- } \\
\text { mento }\end{array}$ & $\begin{array}{l}\text { Aprendi- } \\
\text { zagem }\end{array}$ & $\begin{array}{c}\text { Empodera- } \\
\text { mento }\end{array}$ & \begin{tabular}{|c} 
Territoriali- \\
zação
\end{tabular} & $\begin{array}{c}\text { Gestão } \\
\text { Territorial }\end{array}$ & \\
\hline Porcentual & $11 \%$ & $22 \%$ & $17 \%$ & $22 \%$ & $11 \%$ & $5 \%$ & \\
\hline
\end{tabular}

FONTE ELABORAÇÃO PRÓPRIA

Os primeiros quatro princípios, em relação aos quais os graus de discordância variaram entre 34 e $56 \%$, justificam alguns comentários, pois demonstram aspectos da govenança territorial que representam os desafios mais significativos.

Primeiro, na avaliação dos atores inquiridos o Estado não está desempenhando seu papel de articulador principal nas práticas de governança das experiências analisadas. Significa isto que, na percepção dos atores inquiridos, o Estado não tem sido eficaz. Os procedimentos metodológicos aplicados não permitem concluir sobre as razóes da ineficácia, o que merece ser aprofundado em futuros estudos. Em segundo lugar, está colocada a questão da integração das políticas públicas com incidência nos territórios, indicando que há sobreposição de políticas. Em terceiro lugar aparece a questáo da resistência à mudança, a Resiliência, também avaliada negativamente. Este aspecto é significativo, considerando que estas experiências têm como foco a atividade empresarial, na qual estar aberto à mudança, às expectativas do mercado em transformação constante, na maioria das vezes é decisivo para a sustentabilidade das experiências.

No que se refere ao quarto aspecto, a eficácia das políticas, as respostas dos inquiridos indicam que as políticas com impacto territorial, não estão focadas nos resultados esperados pelos atores territoriais ou em objetivos definidos coletivamente. Outros três princípios recebem uma avaliação de discordância em $28 \%$ das respostas, o que é significativo. Segundo os inquiridos, indicam problemas, respectivamente, em questóes de liderança, de protagonismo social e de integração horizontal das políticas territoriais. Este último aspecto tem relação com a questão da integração das políticas públicas, ambas com impacto nos territórios, também avaliada negativamente. 
Das dimensôes das práticas de governança territorial, a que tem maior incidência de respostas discordantes é a que se refere às relaçóes entre os atores nos processos associativos, seguido da dimensão referente à coordenação das políticas nos territórios. Tal situação tem relação com o que foi comentado a respeito da desintegração das políticas, sejam de origem estatal ou não, além das questôes referentes aos problemas de liderança e resistência às mudanças. Coincide com percepçóes já formadas quando da visita a algumas experiências, ao conversar com atores envolvidos e dirigentes.

\section{Consideraçóes finais}

Compartilhamos a concepçáo de autores como Abagli (2004), de que a apropriação do território unicamente a partir da sua capacidade de atrair investimentos e gerar lucratividade tende a consumir de forma predatória os recursos tanto naturais, quanto sociais e culturais. Em contrapartida, o desenvolvimento, tendo como suporte uma noção sistêmica e inclusiva de território, tende a estimular os laços de identificação e solidariedade, podendo dar uma maior garantia de sustentabilidade no longo prazo. A primeira opção está presente quando se observa que as estratégias de especificação de ativos territoriais utilizam o associativismo como forma de viabilização de negócios lucrativos e não como princípio, conforme está previsto na legislação brasileira sobre Indicações Geográficas ou na legislação sobre outras formas organizacionais correlatas em Portugal.

Antes de ser uma acusação, trata-se de uma constatação, o que reafirma a hipótese orientadora deste estudo de que nas experiências de especificação de ativos territoriais este aspecto não só não parece ser devidamente considerado como, em geral, não se baseia em sistemas eficientes e justos de governança territorial. Ou seja, o fato de que os sinais distintivos dos territórios têm uma dimensão coletiva e devem ser mobilizados a partir de interesses compartilhados parece não ser devidamente considerado em muitas das experiências deste tipo.

Das demais questóes evidenciadas pela presente investigação, as principais estão sintetizadas no quadro 5 .

Além da síntese que consta no quadro 5, destacamos questóes relacionadas com a estrutura de governança territorial das IGs (Brasil) e Doc/Dop (Portugal). Nosso propósito era avaliar a contribuição efetiva dos sistemas de governança territorial de estratégias baseadas na especificação de ativos territoriais para a sustentabilidade social, econômica e ambiental dos territórios envolvidos. Ou seja, compreender se as estruturas de governança territorial de tais experiências estão ou não apoiadas em mecanismos institucionais adequados.

Nesse aspecto são constatados os maiores diferenciais. Experiências em Portugal estão estruturadas na forma de comissóes nacionais, ou associaçôes, que articulam a produção quanto ao apoio técnico, normatizaçóes legais, regulação do volume da produçáo, inserção dos produtos no mercado e marketing geral, principalmente no setor industrial. No Brasil, as associaçóes que articulam experiências têm dificuldades para aglutinar os envolvidos. Mesmo em Portugal, há experiências em que as associaçóes são pouco operantes, apenas cumprindo questóes de legislação. 


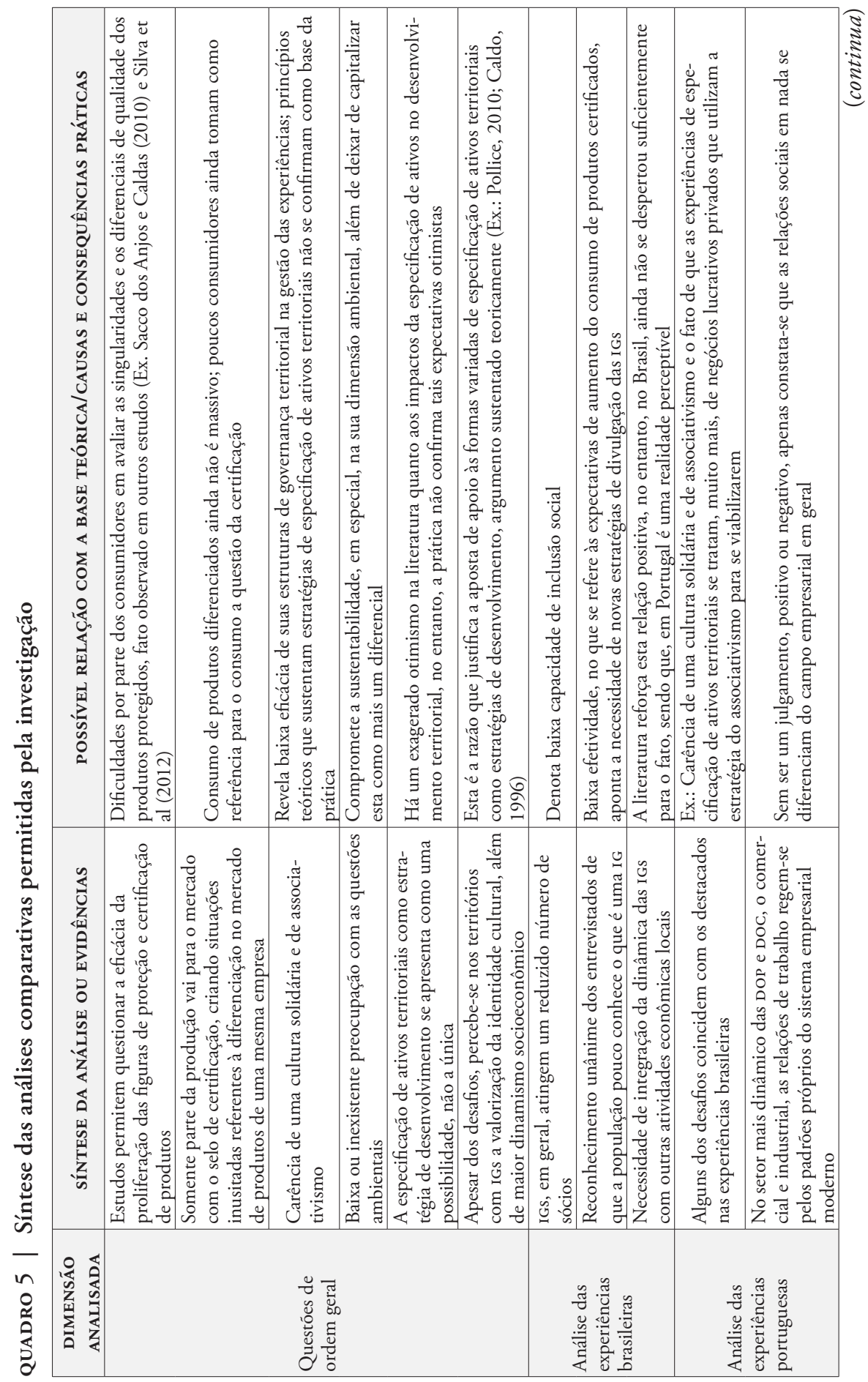




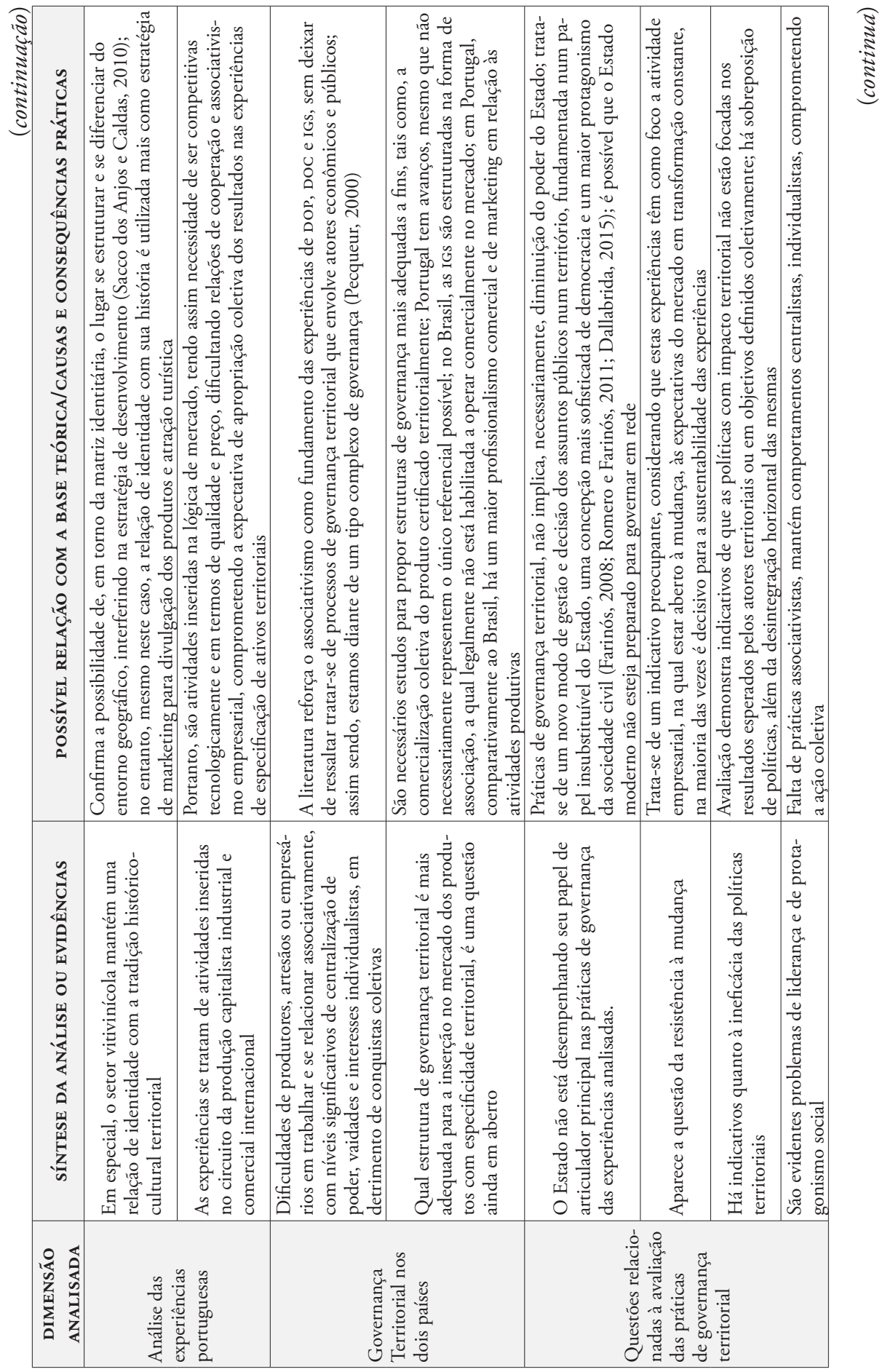




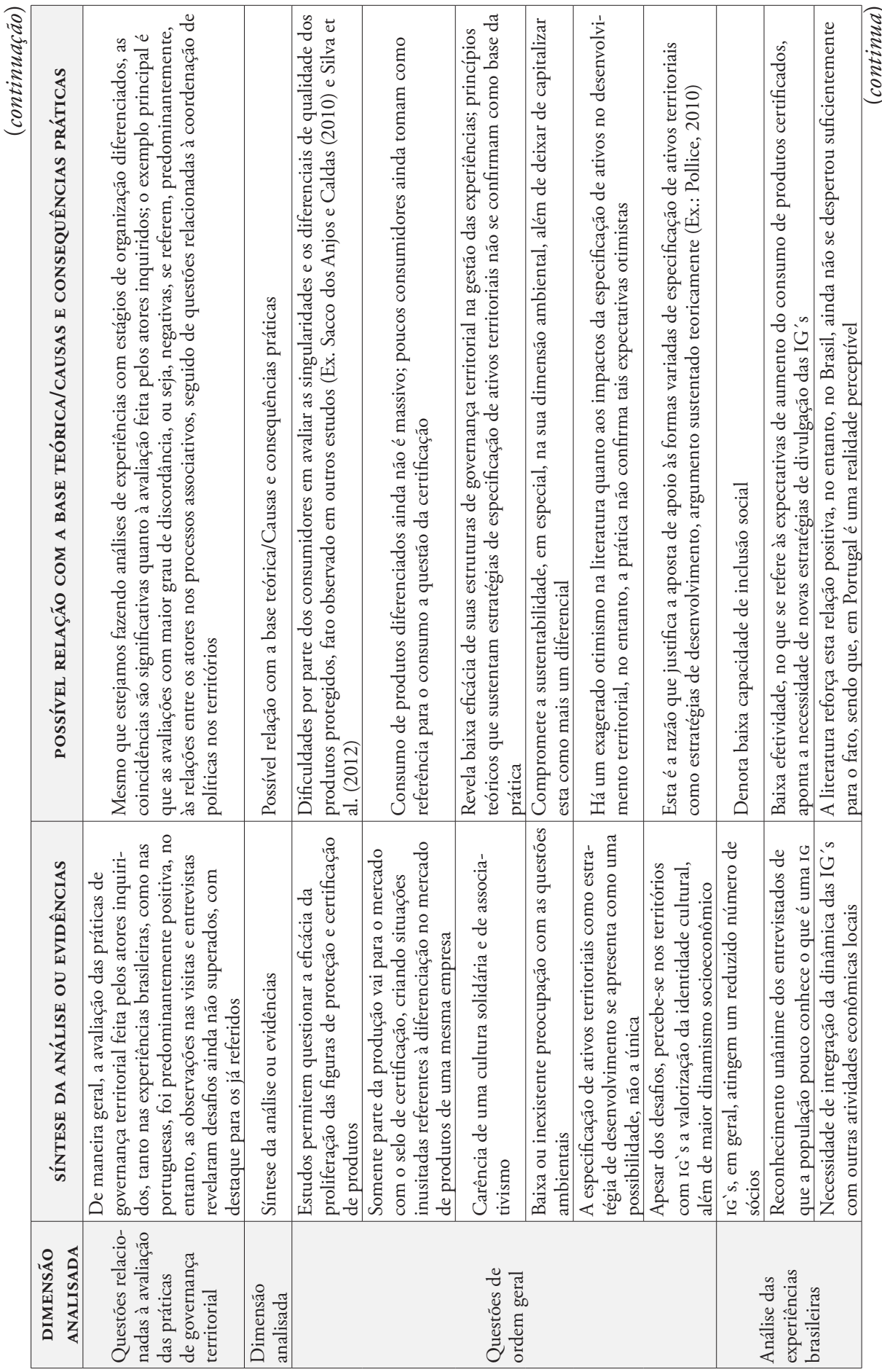




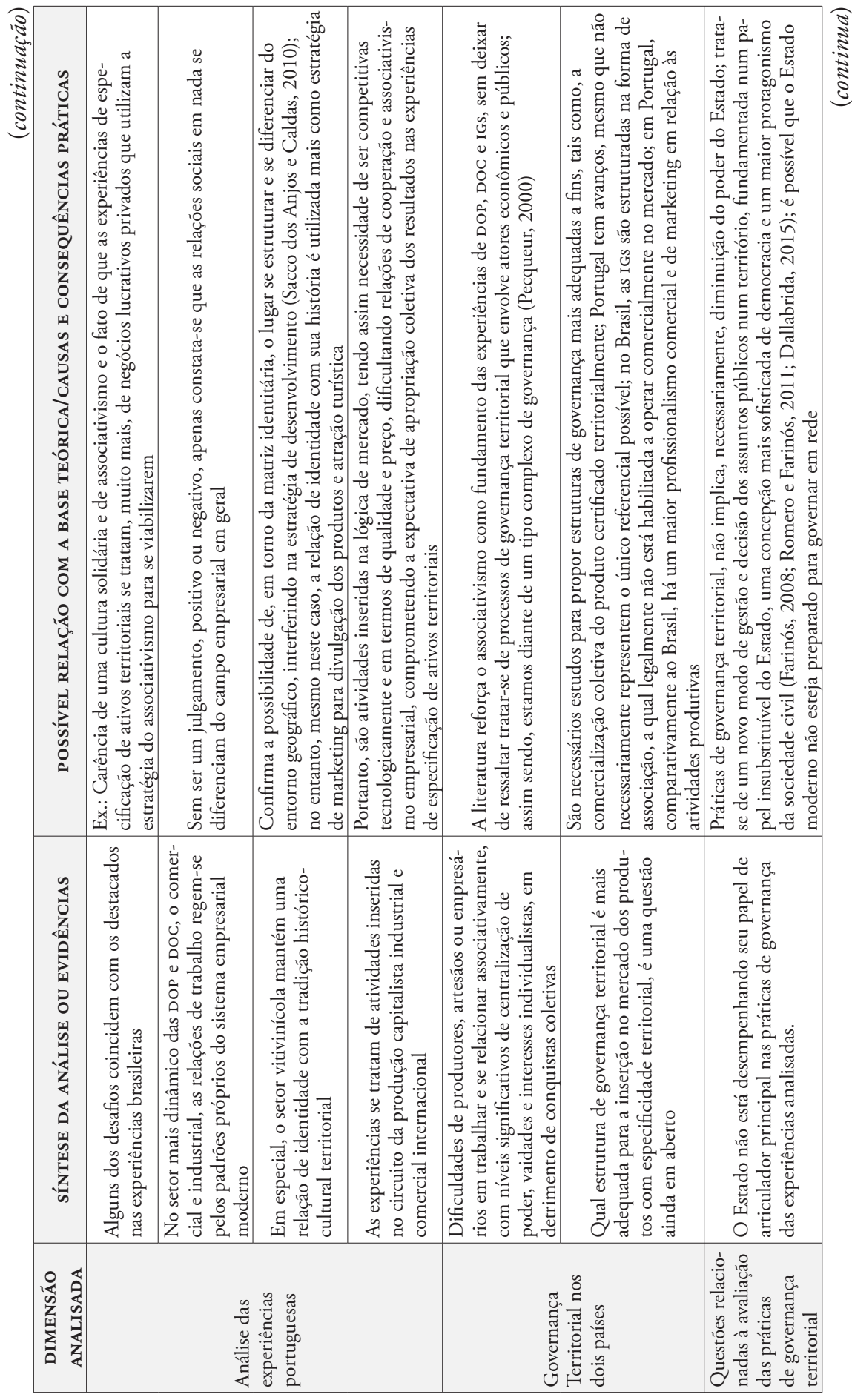




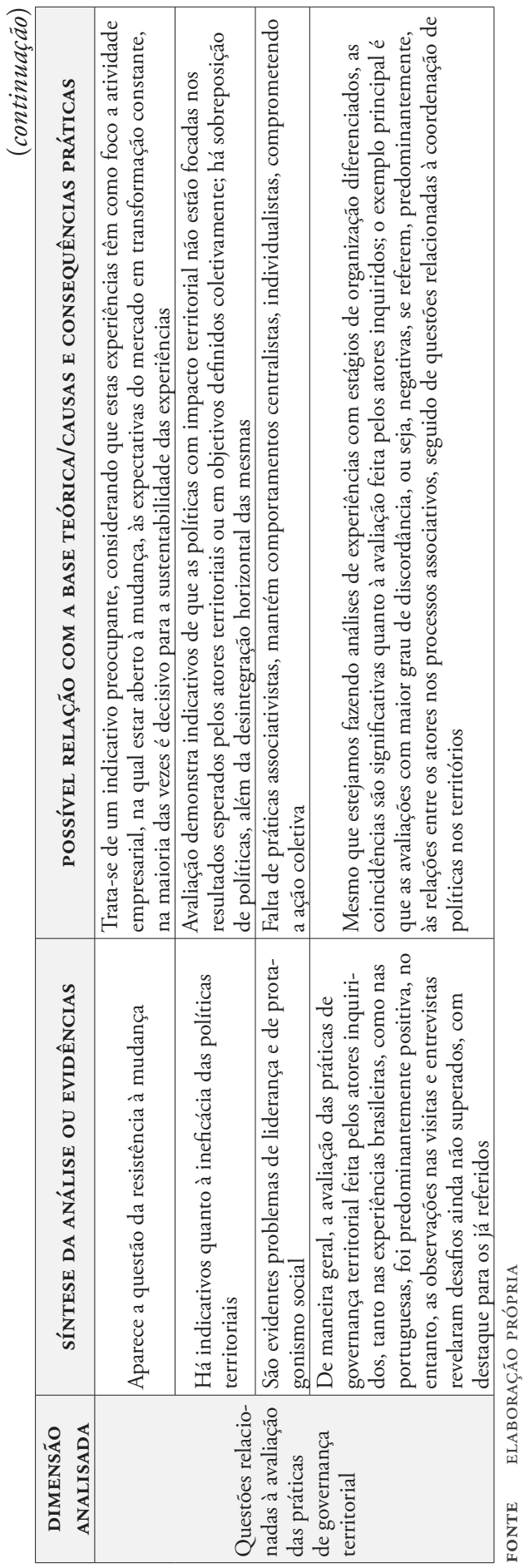


Sem a pretensão de apontar 'padrôes ideais', apenas fazemos referência que esta é uma dimensão que merece estudos mais aprofundados, para indicar qual a estrutura de governança territorial que melhor venha contribuir para a sustentabilidade das experiências de especificaçáo de ativos territoriais em contextos políticos, socioeconômicos, institucionais e culturais distintos.

Por fim, quanto ao impacto da especificação de ativos na qualificação no processo de desenvolvimento territorial, é notório que as regióes envolvidas por tais experiências apresentam um maior dinamismo socioeconômico e cultural. No entanto, reafirmamos o que está presente em boa parte da bibliografia: é uma opção, não necessariamente a única e, em alguns casos, nem é a mais significativa. Outros estudos são necessários para aprofundar o debate e propor indicativos para a superação dos desafios apontados.

\section{Referências bibliográficas}

Albagli, S. (2004). Território e territorialidade. In: V. Lages, C. Braga \& G. Morelli, Territórios em movimento: cultura e identidade como estratégia de inserção competitiva (pp. 24-69). Brasília: Sebrae.

Benko, G. \& Pecqueur, B. (2001). Os recursos de territórios e os territórios de recursos. Geosul, 16(32), 31-50. Disponível em https://periodicos.ufsc.br/index.php/geosul/article/ view/14006

Brandão, C. A. (2007). Território e desenvolvimento: as múltiplas escalas entre o local e o global. Campinas: Editora da Unicamp.

Caldo, C. (1996). Geografia humana. Palermo: Palumbo.

CMMAD-Comissão Mundial sobre Meio Ambiente e Desenvolvimento. (1991). Nosso Futuro Comum. (2a ed.). Rio de Janeiro: Editora da Fundação Getúlio Vargas.

Dallabrida, V. R. (2006). Território. In D. R Siedenberg (Org.), Dicionário do Desenvolvimento Regional (pp. 161-162). Santa Cruz do Sul: Editora Edunisc.

Dallabrida, V. R. (2015). Governança territorial: do debate teórico à avaliação da sua prática. Análise Social, L(2o), 215, 304-328. Disponível em http://analisesocial.ics.ul.pt/ documentos/AS_215_a04.pdf

Farinós, J. (2008). Gobernanza territorial para el desarrollo sostenible: estado de la cuestión y agenda. Boletin de la A.G.E., (46), 11-32. Disponível em http://www.dhl.hegoa.ehu.es/ ficheros/0000/0563/Gobernanza.pdf

Fernández, V. R. \& Dallabrida, V. R. (2008). Nuevo regionalismo y desarrollo territorial en ámbitos periféricos. Aportes y redefiniciones en la perspectiva latinoamericana. In A. Amin, V. R. Fernández \& J. I. Vigil (Comps.), Repensando el desarrollo regional. Contribuciones globales para una estrategia latinoamericana (pp. 481-519). Buenos Aires: Editorial Miño y Dávila.

Ferrão, J. (2010). Governança e ordenamento do território. Reflexôes para uma governança territorial eficiente, justa e democrática. Prospectiva e Planeamento, (17), 129-139. 
Ferrão, J. (2013). Governança, governo e ordenamento do território em contextos metropolitanos. In: Á. Ferreira, J. Rua, G. J. Marafon \& A. C. P. Silva (Orgs.). Metropolização do Espaço: Gestão Territorial e Relaçōes Urbano-Rurais (pp. 255-281). Rio de Janeiro: Editora Consequência.

Flores, M. (2007). La identidad cultural del territorio como base de una estrategia de desarrollo sostenible. Revista Opera, (7), 35-54. Disponível em http://www.redalyc.org/articulo. oa?id $=67500703$

Friedman, T. L. (2005). O Mundo é Plano: uma Breve História do Século XXI. Lisboa: Actual Editora.

Froehlich, J. M. (Org). (2012). Desenvolvimento territorial. produção, identidade e consumo. Ijuí, Rs: Editora Unijuí.

Haesbaert, R. (2006). Concepçóes de território para entender a desterritorialização. In M.Santos et al. Território, territórios: ensaios sobre ordenamento territorial (pp. 43-70) ( $2^{\text {a }}$ ed.). Rio de Janeiro: DP\&A.

O'Brien, R. (1992). Global financial integration: The end of Geography. London: The Royal Institute of International Affairs.

Pecqueur, B. (2000). Le développement local. 2èm edition. Paris: Syros.

Pecqueur, B. (2009). A guinada territorial da economia global. Política \& Sociedade, 8(14), 79105. http://dx.doi.org/10.5007/2175-7984.2009v8n14p79

Pollice, F. (2010). O papel da identidade territorial nos processos de desenvolvimento local. (Tradução de Andrea Galhardi de Oliveira, Renato Crioni, Bernadete Aparecida Caprioglio de Castro Oliveira). Espaço e Cultura, (27), 7-23. Disponível em http:// www.e-publicacoes.uerj.br/index.php/espacoecultura/article/view/3539

Raffestin, C. (1993). Por uma geografia do poder. São Paulo: Ática.

Raffestin, C. (2015). Prefácio. In: M. A. Saquet, Por uma Geografia das Territorialidades e da temporalidades. Uma concep̧̧ão multidimensional voltada para a cooperação e para o desenvolvimento territorial (pp. 9-19). Rio de Janeiro: Consequência.

Romero, J. \& Farinós, J. (2011). Redescubriendo la gobernanza más allá del buen gobierno. Democracia como base, desarrollo territorial como resultado. Boletin de la A.G.E., (56), 295-319. Disponível em dialnet.unirioja.es/descarga/articulo/3722490/1.pdf

Sacco Dos Anjos, F. \& Caldas, N. V. (2010). Indicaciones geográficas, desarrollo e identidad territorial. Agricultura Familiar en España, (1), 207-214. Disponível em http://www. upa.es/anuario_2010/pag_207-214_saccodosanjos.pdf

Santos, M. A. (2005). O retorno do território. OSAL: Observatorio Social de América Latina, 6(16), 255-260. Disponível em http://bibliotecavirtual.clacso.org.ar/ar/libros/ osal/osal16/D16Santos.pdf

Saquet, M. A. (2003). Os tempos e os territórios da colonização italiana. O desenvolvimento da colônia Silveira Martins. Porto Alegre: EST Ediçóes.

Saquet, M. A. (2015). Por uma Geografia das territorialidades e das temporalidades. Uma concepção multidimensional voltada para a cooperaçāo e para o desenvolvimento territorial. Rio de Janeiro: Consequência. 
Silva, F. N., Sacco dos Anjos, F., Caldas N. V. \& Pollnow, G. E. (2012). Desafios à institucionalização das Indicaçōes Geográficas no Brasil. DRd - Desenvolvimento Regional em debate, 2(2), 31-44. Disponível em http://www.periodicos.unc.br/index. $\mathrm{php} / \mathrm{drd} / \mathrm{article} /$ view/258

Swyngedouw, E. (2010). Globalización o glocalización? Redes, territorios y reescalamiento. In: V. R. Fernández \& C Brandão, Escalas y políticas del desarrollo regional: desafios para América Latina (pp. 47-75). Buenos Aires: Miño y Dávila. 